INDONESIA ACCOUNTING JOURNAL VOLUME 3, NUMBER 1, YEAR 2021

${ }^{1,2}$ Accounting Programme

Economics and Business Faculty

Yapis Papua University

Jl. Dr. Sam Ratulangi No. 11 Dok. V Atas

Jayapura City, Papua Province,

Indonesia, 99113

${ }^{3}$ Programme of Commerce

Ambon State Polytechnic

Jl. Ir. M. Putuhena Wailela Rumah Tiga

Ambon City, Maluku Province,

Indonesia, 97234

${ }^{4}$ Programme of Commerce

Said Perintah the College of Administrative Sciences

Jl. Nuri, Masohi No. 97511 Wainitu Nusaniwe

Ambon City, Maluku Province,

Indonesia, 97511

${ }^{5}$ Corresponding author

Programme of Commerce

Said Perintah the College of

Administrative Sciences

Jl. Nuri, Masohi No. 97511 Wainitu Nusaniwe

Ambon City, Maluku Province,

Indonesia, 97511

E-mail: eduardtamaela58@gmail.com

Article info:

Received 17 November 2020

Accepted 16 February 2021

Available online 16 February 2021

Keywords: competence; independence; ethics; professional commitment; audit quality

JEL Classification: $\mathrm{H}_{3}, \mathrm{M}_{41}, \mathrm{M}_{42}$

DOI: http://doi.org/10.32400/iaj.31289

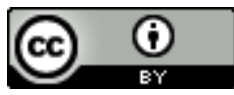

This work is licensed under a Creative Commons

Attribution 4.0

International License.

\section{The relationship of auditor competence and independence on audit quality: An assessment of auditor ethics moderation and professional commitment?}

\author{
Victor Pattiasina ${ }^{1}$ \\ Muhamad Yamin Noch ${ }^{2}$ \\ Herman Surijadi ${ }^{3}$ \\ Muhammad Amin ${ }^{4}$ \\ Eduard Yohannis Tamaela ${ }^{5}$
}

\begin{abstract}
The purpose of this study is to examine and analyze the effect of auditor competence and independence on audit quality as moderated by auditor ethics and professional commitment. The population of this study is the BPKP Auditor Representative of Papua Province with census sampling as the sampling method. Data collection was carried out by direct survey. Hypothesis testing was tested empirically using Moderated Regression Analysis. The results of the study have proven that the competence and independence of auditors has a positive and significant effect on audit quality at BPKP Representatives of Papua Province. It is evidenced by the regression coefficient, which shows that the increase follows competence or independence of auditors increases, as well as the increase of audit quality. The results of this study also show that the interaction or influence of auditor ethics does not moderate the effect of auditor competence on audit quality at BPKP Representatives of Papua Province. Moreover, the interaction of professional commitment does not moderate the effect of auditor independence on audit quality. It is believed that the factor caused the phenomena is that the auditors of BPKP Representative of Papua Province have good values or fundamental principles of ethics as well as professional commitment. The values that have been held so far are relatively relevant or have a lot in common with the auditors' ethics and professional commitment.
\end{abstract}

\section{Introduction}

Legal issues, especially those related to corruption, collusion and nepotism in all their practices such as abuse of authority, bribery, facilitation payments, illegal fees, payment based on collusion and nepotism and the use of state money for personal gain have become the public's attention (Tan and Swan, 2020; Nahuway and Tamaela, 2020; Najib, 2013; Tamaela et al., 2020). As the example, the Enron case shocked the world because of the bankruptcy of the financial 
statements (Holt and Eccles, 2003). It is predicted that the Enron scandal will have an impact on various aspects. First, the emergence of public doubts about financial information; second, regulatory bodies will be more stringent in dealing with financial reports and public accountant office (or $K A P)$; and third, serious attention to the need to separate consulting services and audit services (Ludigdo, 2005).

Christiawan (2002) states that audit quality is determined by two things, namely competence and independence. However, the competence and independence of the auditor will be related to auditor ethics (Samadara, 2020). Lastanti (2005) and Pattiasina (2017) define that expertise as someone who has extensive knowledge and procedural skills shown in the audit experience. Consistently, Setyani (2015) show that auditor competence affects audit quality at the Inspectorate of Boyolali Regency which support Aini (2009) and Samsi et al. (2013) who prove that competence has a positive and significant effect on audit quality. However, it turns out that other researchers convey results that are not in line with the results of the study above, such as those presented by Indriyanto and Nasikin (2014) which find that auditors' educational background, audit experience, auditor training hours and audit structure did not affect the quality of the audits carried out by the Audit Board of the Republic of Indonesia (or BPK RI) Representatives of Bangka Belitung Province.

Another factor that has the potential to affect audit quality is auditor independence. Aini (2009) and Setyani (2015) stated that auditor independence affects audit quality and is also in line with other results by In and Asyik (2019) which also stated that independence affects audit quality. In addition to competency and independence factors, auditors are also required to have ethics in auditing financial statements. Ethics itself aims to help humans act freely but can be accounted for (Najib, 2013).

This study is an extension of the conceptual model of previous studies, including Aini (2009), Hapsari (2011),
Arianingtyas (2014), Gasperz (2014), In and Asyik (2019), Samsi et al. (2013), and Setyani (2015). Based on those findings, this study determines the auditor ethics and auditor commitment as moderating variables that will affect the relationship between auditor competence, auditor independence, and audit quality.

The motivation and objectives of this study include: first, this study is conducted at Financial and Development Supervisory Agency (or BPKP) Representatives of Papua Province to test whether auditor competence and auditor independence affect audit quality with auditor ethics and auditor commitment as moderating variables. The ethics and commitment of the auditors, especially at the BPKP Representative of Papua Province, have never been studied. Second, auditor ethics and auditor commitment which also act as moderating variables in moderating the influence between auditor competence and auditor independence on audit quality, this study tries to test several behavioral development theories, namely auditor competence and auditor independence on audit quality by performing moderating regression analysis (MRA). Also, auditor ethics and auditor commitment are interesting to study because ethical decisions play an important role in which auditors will always be faced with making ethical decisions when performing their duties to audit financial statements.

\section{Literature review}

\section{Theory of planned behavior}

The theory of planned behavior (TPB) is a further development of the theory of reasoned action (TRA). Ajzen (2005) developed TPB by adding a construct that did not yet exist in TRA which called perceived behavioral control. This construct is added in TPB to control individual behavior which is limited by its shortcomings and limitations from the lack of resources used to carry out the behavior.

Ajzen (2005) states that the theory of planned behavior (TPB) have two features as follows. First, this theory assumes that 
perceived behavior control has motivational implications for interest. People believing that they do not have the available resources or do not have the opportunity to perform certain behaviors may not develop strong intentional behavior to do so. Even though they have a positive attitude towards their behavior and believe that others will agree if they do this behavior. Thus it is hoped that there will be a relationship between perceived behavioral control and intention that is not mediated by attitudes. The second feature is the possibility of a direct relationship between perceived behavioral control and behavior. In many instances, the performance of a behavior depends not only on the motivation to perform it but also on sufficient control over the behavior. Thus, perceived behavior control can influence behavior indirectly through intention, and can also predict behavior directly. According to Ajzen (2005), the theory of planned behavior explicitly concerns the possibility that behavior is not completely under full control so the concept of perceived behavior control is added to address this kind of behavior. If all behavior can be fully controlled by the individual, that is, behavior control that is close to the maximum, then the theory of planned behavior returns to a theory of reasoned action.

\section{Quality of audit}

Francis (2004) defines that audit quality as the possibility (joint probability) where an auditor finds and reports about a violation in his client's accounting system. The ability to find material misstatements in the auditee's financial statements depends on the competence of the auditors, while the willingness to report the findings of these misstatements depends on their independence. AAA Financial Accounting Committee as followed by Christiawan (2002) states that audit quality is determined by two things, namely competence (expertise) and independence. Both of these have a direct effect on audit quality. Furthermore, the perceptions of users of financial statements on audit quality are a function of their perceptions of the independence and expertise of auditors. Based on the above definition of the quality of the audit, it may be concluded that the quality of the audit is a possibility that the auditor may, when auditing the client's financial statements, identify infringements that have occurred in the client's accounting system and report them to the audited financial report.

\section{Competence}

Lastanti (2005) defines expertise or competence as someone who has extensive knowledge and procedural skills that are shown in audit experience, so it can be interpreted that the competence of an auditor is an auditor with sufficient and explicit knowledge and experience who can audit objectively, accurately, and carefully (Tammubua and Pattiasina, 2019). The need for audits to be carried out by BPKP uses the State Financial Audit Standards (SFAS) as stipulated in the Regulation of the Supreme Audit Agency of the Republic of Indonesia Number 1 of 2007. The first statement of the SFAS general standard is "collective auditors must have adequate professional skills to carry out audit tasks". According to Francis (2004), competence is not only influenced by formal education but many other factors that influence it, namely knowledge and experience.

\section{Independence}

Mulyadi (2008:26) explains that independence is a mental attitude that is free from influence, not controlled by other parties, and it does not depend on others. Independence also means that the existence of honesty within the auditor in considering facts and the existence of an objective, impartial considerations within the auditor in formulating and expressing his opinion. Auditors often encounter difficulties in maintaining an independent mental attitude. SFAS in the second general standard statement states "in all matters relating to examination work, the examining and examining organizations must be free in their mental attitude and appearance from personal, external, and organizational disturbances that can affect their 
independence". Based on this statement, the examining organization and its examiners (auditors) are responsible for maintaining their independence in such a way that opinions, conclusions, considerations or recommendations from the results of the examination carried out are impartial and considered impartial by any party (Wulandari and Tjahjono, 2011; Seralurin et al., 2020).

\section{Professional commitment}

Jeffrey et al. (1996) state that commitment to the profession is the intensity of identification and involvement of individuals with their profession. This identification requires some level of agreement between individuals with the goals and values that exist in the profession, including moral and ethical values. Jeffrey et al. (1996) examine the relationship between professional commitment, ethical understanding, and obedience to rules and find that accountants who have a strong professional commitment, their behavior leads to obedience to regulations compared to accountants who have low professional commitment.

\section{Research model}

Figure 1 presents that the conceptual model which built based on the phenomena that occur, the problems, and the objectives to be achieved for this study, the relationship between the theoretically variables and the study of previous studies.

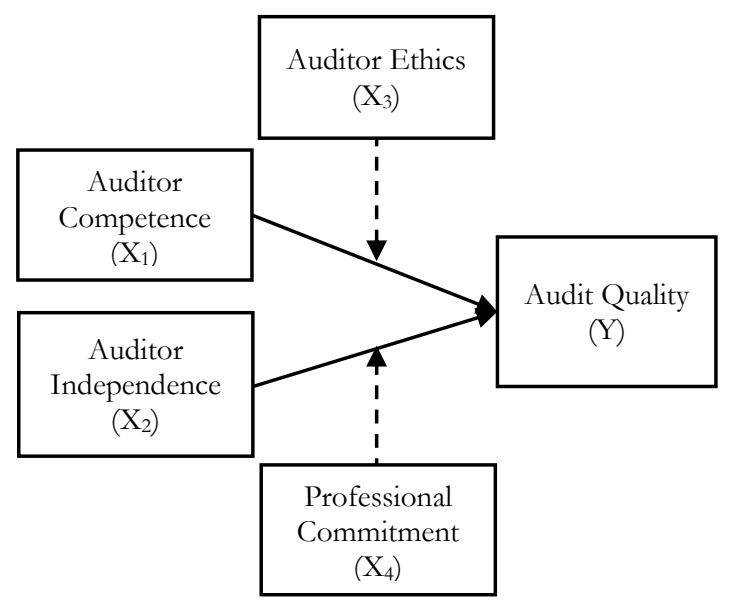

Figure 1. Research model
Based on Figure 1, this study develops 3 models (derived from the main research model in Figure 1) as described in Figure 2, Figure 3, and Figure 4.

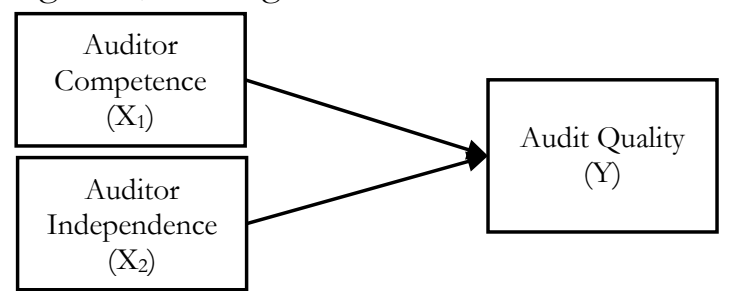

Figure 2. Research model 1

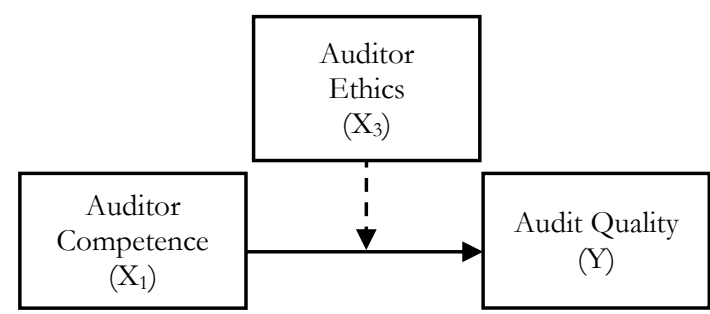

Figure 3. Research model 2

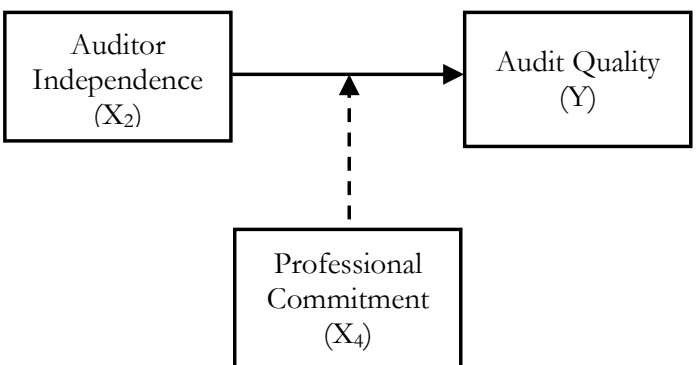

Figure 4. Research model 3

\section{Hypothesis development}

The effect of auditor competence on audit quality

Francis (2004) states that generally there are five types of knowledge that auditors must have, namely: (1) general auditing knowledge; (2) functional areas; (3) accounting issues; (4) specific industries; and (5) general business knowledge and problem-solving. General auditing knowledge, such as audit risk, audit procedures are mostly obtained from universities, partly from training and experience. Mayangsari (2003) states that experienced auditors have the advantage of detecting errors, understanding errors accurately, and finding the causes of errors. Auditors who have experience will have a better understanding and are better able to provide reasonable explanations for errors in the financial statements. Christiawan 
(2002) states that the higher the competence of the auditors, the better the quality of the audit results which is consistent with Aprianti (2010), Samsi et al. (2013), and Tjun et al. (2012). Based on explanation, the hypothesis built as follows.

H1: Auditor competence has a positive effect on audit quality.

\section{The effect of auditor independence on} audit quality

Wulandari and Tjahjono (2011) state that BPKP as the government's internal auditor is often questioned for its independence because of the political involvement in all lines of government in Indonesia, meaning that independence is essential in conducting audits. Meanwhile, Christiawan (2002) finds that independence has a significant effect on audit quality where the auditor must be able to collect any information needed in making audit decisions where an independent attitude must support this. Consistently, the similar results also found by Alim et al. (2007), Najib (2013), and Samsi et al. (2013). Based on explanation, the hypothesis built as follows.

H2: Auditor independence has a positive effect on audit quality.

The effect of interaction of auditor competence and auditor ethics on audit quality

Competence if supported by ethical compliance can produce quality audits. It is in line with the results of Aprianti (2010), namely the interaction of competence and ethical compliance of public accountants affects audit quality. Based on explanation, the hypotheses built as follows.

H3: Auditor competence has a positive effect on audit quality in moderated by auditor ethics.

The effect of interaction of auditor independence and professional commitment on audit quality

Jeffrey et al. (1996) examine the relationship between independence and professional commitment, ethical understanding, and obedience to rules, showing that accountants who have strong professional commitment and independence have more behavior towards rule compliance. Based on explanation, the hypothesis built as follows.

H4: Auditor independence has a positive effect on audit quality moderated by professional commitment.

\section{Research methods}

The method used in this study is explanatory research. The population of this study is auditors at the BPKP Representative of Papua Province with total 61 people. It is $92.4 \%$ of the total sample. The data analysis technique is carried out utilizing the research instrument test and Moderate Regression Analysis (MRA) by first testing the classical assumptions. This study conducts multiple regression analysis and MRA regression used to test the equation model for hypotheses 1 and 2 (Eq. 1), hypotheses 3 (Eq. 2), and hypotheses 4 (Eq. 3).

$\mathrm{Y}=\alpha+\beta_{1} \mathrm{X}_{1}+\beta_{2} \mathrm{X}_{2}+\varepsilon$

$Y=\alpha+\beta_{1} X_{1}+\beta_{3} X_{3}+\beta_{1} X_{1} * X_{3}+\varepsilon \quad$ (Eq. 2) $\mathrm{Y}=\alpha+\beta_{2} \mathrm{X}_{2}+\beta_{4} \mathrm{X}_{4}+\beta_{2} \mathrm{X}_{2} * \mathrm{X}_{4}+\varepsilon \quad$ (Eq. 3)

The dependent variable is audit quality $(\mathrm{Y})$ and the independent variables are competence (X1) and independence (X2), while auditor ethics (X3) and professional commitment $(\mathrm{X} 4)$ are moderating variables. The operational definitions with its measurements are as follows.

1. Audit quality. Audit quality acts as a joint probability, in which an auditor finds and reports about a violation in his client's accounting system. This variable is adopted from In and Asyik (2019). The measurement of this variable uses a Likert scale starting from strongly disagree with a score of 1 to strongly agree with a score of 5 .

2. Auditor competence. Competence as someone who has extensive procedural knowledge and skills demonstrated in the audit experience. This variable is adopted from In and Asyik (2019). Measurement of this variable uses a Likert scale starting from strongly disagree with a score of 1 to strongly agree with a score of 5 . 
3. Auditor independence. Auditors must have neutral and unbiased attitude and avoid any interest in planning, implementing and reporting on the work they do. This variable is adopted from In and Asyik (2019). Measurement of this variable uses a Likert scale starting from strongly disagree with a score of 1 to strongly agree with a score of 5 .

4. Auditor etbics. An ethic is phenomena in which the auditor must comply with a predetermined code of ethics. The audit must refer to the audit standards. This variable is adopted from In and Asyik (2019). Measurement of this variable uses a Likert scale starting from strongly disagree with a score of 1 to strongly agree with a score of 5 .

5. Professional commitment. The professional commitment referred to in this study is the intensity of identification and involvement of individuals with their profession. This variable is adopted from Hapsari (2011). Measurement of this variable uses a Likert scale starting from strongly disagree with a score of 1 to strongly agree with a score of 5 .

\section{Results and discussion}

Research instrument quality test

Testing instruments in this study are intended to test the validity or validity of the questionnaire. Furthermore, this test will be discussed in two parts, namely the validity test and the reliability test. This study uses Product Moment Person correlation for validity testing, where the validity of the instrument can be determined by comparing the Product Moment Person correlation index with a significance of $5 \%$. This study uses Cronbach's Alpha for reliability test where an instrument can be said to be reliable if it has a reliability coefficient value greater than or equal to 0.6 , meaning that if $\alpha=0.6$. Table 1 shows the results of the validity and reliability tests. The results of the validity test above indicate that all variables are valid because the significance level is less than 0.05 and all of the variables have a coefficient above 0.60 so that all the data could be said to be reliable, which means that this data is feasible to be continued in the next stage of data processing.

Table 1. Results of validity and reliability tests

\begin{tabular}{|c|c|c|c|c|c|c|}
\hline \multirow[b]{2}{*}{ Variable } & \multirow{2}{*}{$\begin{array}{l}\text { Total } \\
\text { item }\end{array}$} & \multicolumn{3}{|c|}{ Validity } & \multicolumn{2}{|c|}{ Reliability } \\
\hline & & $\mathbf{r}$ & Sig. & Note & $\begin{array}{c}\text { Alpha } \\
\text { coefficient }\end{array}$ & Note \\
\hline Auditor Competence $\left(\mathrm{X}_{1}\right)$ & 5 & $0.703-0.893$ & 0.000 & Valid & 0.875 & Reliable \\
\hline Auditor Independence $\left(\mathrm{X}_{2}\right)$ & 6 & $0.752-0.834$ & 0.000 & Valid & 0.888 & Reliable \\
\hline Auditor Ethics $\left(\mathrm{X}_{3}\right)$ & 5 & $0.768-0.845$ & 0.000 & Valid & 0.863 & Reliable \\
\hline Professional Commitment $\left(\mathrm{X}_{4}\right)$ & 6 & $0.682-0.883$ & 0.000 & Valid & 0.892 & Reliable \\
\hline Audit Quality $(\mathrm{Y})$ & 8 & $0.564-0.865$ & 0.000 & Valid & 0.884 & Reliable \\
\hline
\end{tabular}

\section{Classic assumption tests}

Normality test. Table 2 presents the result of Kolmogorov Smirnov test as normality test for this study. This test compares the distribution of data with the distribution selected. Testing the normality of a data using the Kolmogorov Smirnov test is done by comparing the value of $\mathrm{D}$ count and the amount of $\mathrm{D}$ table with the criteria if $\mathrm{D}$ count more than from $\mathrm{D}$ table then the data is said to be normally distributed. The result shows that the Kolmogorov Smirnov value is 0.771 , which is the $\mathrm{D}$ count. Based on the Kolmogorov Smirnov test, it is known that the value of the $\mathrm{D}$ table is 0.172 . These results indicate that $\mathrm{D}$ count more than $\mathrm{D}$ table $(0.771>0.172)$ means that the residual error is normally distributed. 
Table 2. Normality test: One-Sample Kolmogorov-Smirnov Test

\begin{tabular}{|c|c|c|c|c|}
\hline & & $\begin{array}{c}\text { Unstandardized Residual } \\
\text { - Model } 1 \\
\end{array}$ & $\begin{array}{c}\text { Unstandardized Residual } \\
\text { - Model } 2 \\
\end{array}$ & $\begin{array}{c}\text { Unstandardized Residual } \\
\text { - Model } 3\end{array}$ \\
\hline \multicolumn{2}{|l|}{$\mathrm{N}$} & 61 & 61 & 61 \\
\hline \multirow[b]{2}{*}{$\begin{array}{l}\text { Normal } \\
\text { Parameters }\end{array}$} & Mean & 0.0000000 & 0.0000000 & 0.0000000 \\
\hline & $\begin{array}{l}\text { Std. } \\
\text { Deviation }\end{array}$ & 0.68753907 & 0.02117943 & 0.02251012 \\
\hline \multirow{3}{*}{$\begin{array}{l}\text { Most Extreme } \\
\text { Differences }\end{array}$} & Absolute & 0.099 & 0.138 & 0.105 \\
\hline & Positive & 0.099 & 0.081 & 0.105 \\
\hline & Negative & -0.080 & -0.138 & -0.087 \\
\hline \multirow{2}{*}{\multicolumn{2}{|c|}{$\begin{array}{l}\text { Kolmogorov-Smirnov Z } \\
\text { Asymp. Sig. (2-tailed) }\end{array}$}} & 0.771 & 0.138 & 0.105 \\
\hline & & 0.591 & 0.006 & 0.094 \\
\hline
\end{tabular}

b. Calculated from data.

Heteroscedasticity test. Heteroscedasticity testing in this study is carried out using the Glejser test which regress the residual absolute value of the independent variable (Ghozali, 2005:48). Table 3 shows that none of the independent variables statistically affect the dependent variable which means that the regression model does not contain heteroscedasticity as the magnitude of the probability is above 0.05 as the level of confidence.

Table 3. Heteroscedasticity test: Glejser test

\begin{tabular}{lccc}
\hline \multicolumn{1}{c}{ Variable } & Model 1 & Model 2 & Model 3 \\
\hline Auditor Competence $\left(\mathrm{X}_{1}\right)$ & 0.737 & 0.049 & 0.039 \\
Auditor Independence $\left(\mathrm{X}_{2}\right)$ & 0.605 & & 0.043 \\
Auditor Ethics $\left(\mathrm{X}_{3}\right)$ & & & 0.040 \\
Professional Commitment $\left(\mathrm{X}_{4}\right)$ & & -0.01 & -0.01 \\
Auditor Ethics Moderation $\left(\mathrm{X}_{1} \cdot \mathrm{X}_{3}\right)$ & & \\
Professional Commitment Moderation $\left(\mathrm{X}_{2} \cdot \mathrm{X}_{4}\right)$ & & & -0.04 \\
\hline
\end{tabular}

Dependent variables are absolute residual of Model 1, absolute residual of Model 2, and absolute residual of Model 3

Multicollinearity test. The multicollinearity test uses the Variance Inflation Factor (VIF) value or the variance increase factor. If the VIF value is greater than 10 , there will be multicollinearity, on the other hand, if the VIF is smaller than 10, there will be no multicollinearity. Table 4 presents that that the tolerance value is close to 1 and that the VIF value is below 10, which means that there is no multicollinearity between the independent variables in this analysis.

Table 4. Multicollinearity test results

\begin{tabular}{|c|c|c|c|c|c|c|}
\hline \multirow{2}{*}{ Variable } & \multicolumn{2}{|c|}{ Model 1 } & \multicolumn{2}{|c|}{ Model 2} & \multicolumn{2}{|c|}{ Model 3} \\
\hline & Tolerance & VIF & Tolerance & VIF & Tolerance & VIF \\
\hline Auditor Competence $\left(\mathrm{X}_{1}\right)$ & 0.281 & 3.555 & 0.342 & 2.927 & & \\
\hline Auditor Independence $\left(\mathrm{X}_{2}\right)$ & 0.281 & 3.555 & & & 0.242 & 4.126 \\
\hline Auditor Ethics $\left(\mathrm{X}_{3}\right)$ & & & 0.357 & 2.800 & & \\
\hline Professional Commitment $\left(\mathrm{X}_{4}\right)$ & & & & & 0.228 & 4.385 \\
\hline Auditor Ethics Moderation $\left(\mathrm{X}_{1} \cdot \mathrm{X}_{3}\right)$ & & & 0.780 & 1.282 & & \\
\hline Professional Commitment Moderation $\left(\mathrm{X}_{2} \cdot \mathrm{X}_{4}\right)$ & & & & & 0.774 & 1.293 \\
\hline
\end{tabular}

Hypothesis equation models test. The results of hypothesis testing (hypotheses 1, 2, 3 and 4) using multiple regression analysis in the first equation are shown in Table 5 . The first hypothesis proposed in this study is that the competence of auditors affects audit quality. Based on the table above, it is known that the $t$ value is 10,414 which is greater than the $t$ table of 1,999 with a significance of 0.000 which is also smaller than the $\mathrm{p}$-value
0.05 so that $\mathrm{Ha}$ is accepted and $\mathrm{H} 0$ is rejected, meaning that the hypothesis is accepted or auditor competence has a positive and significant effect on audit quality at BPKP Representatives of Papua Province.

The second hypothesis proposed in this study is that auditor independence affects audit quality. Based on the results of the above analysis, it is known that the t-value 
of the auditor independence coefficient is 9,710 , which is greater than the t-table of 1,999. Next, the value of 0.000 , which is also lower than the p-value of 0,05 , means $\mathrm{Ha}$ is accepted, and $\mathrm{H} 0$ is rejected. The hypothesis is accepted since the auditor's independence has a positive effect and significant impact on audit quality at BPKP Representatives of Papua Province. The results also indicate that the level of determination or feasibility for the model of this study is 0.957 or 95.7 per cent, which means that the quality of the audit can be explained very well by the competence and independence variables of the auditor. In comparison, other variables outside the model of this study explain only 4.3 percent.

The third hypothesis proposed is that auditor competence affects audit quality moderated by auditor ethics. Based on the results of the analysis, it is known that the moderation $t$ value of auditors' ethics is 0.003 with a significance of 0.812 which is greater than the p-value 0.05 so that $\mathrm{Ha}$ is rejected or $\mathrm{H} 0$ is accepted, which means that the hypothesis is rejected or auditor ethics does not moderate the effect of auditor competence on audit quality at BPKP Representative of Papua Province.

The final hypothesis proposed is that auditor independence has an effect on audit quality moderated by professional commitment. Based on the results of the analysis, it is known that the moderate $t$ value of professional commitment is -0.004 with a significance of 0.631 which is greater than the p-value 0.05 so that $\mathrm{Ha}$ is rejected or $\mathrm{HO}$ is accepted, which means that the hypothesis is rejected or professional commitment does not moderate the effect of auditor independence on audit quality BPKP Representative of Papua Province.

Table 5. Hypothesis equation models test

\begin{tabular}{lccc}
\hline \multicolumn{1}{c}{ Variable } & Model 1 & Model 2 & Model 3 \\
\hline Auditor Competence (X1) & $0.737^{*}$ & $0.847^{*}$ & $0.595^{*}$ \\
Auditor Independence (X2) & $0.605^{*}$ & & $0.621^{*}$ \\
Auditor Ethics (X3) & & & $0.614^{*}$ \\
Professional Commitment (X4) & & -0.003 & -0.004 \\
Auditor Ethics Moderation (X1.X3) & & & 0.944 \\
Professional Commitment Moderation (X2.X4) & 0.957 & 0.951 & \\
Adjusted R Square & &
\end{tabular}

* is significant at $5 \%$. Dependent variable is Audit Quality $(\mathrm{Y})$

\section{Discussion}

\section{Effect of Auditor Competence on Audit Quality at BPKP Representatives of Papua Province}

The results of the above analysis prove that the competence of auditors at BPKP Representatives of Papua Province has a positive and significant effect on audit quality. This can be proven by the regression coefficient, which shows that if the competence of auditors at BPKP Representatives of Papua Province increases, the increase will be followed by an increase in audit quality. Thus it can be said that increasing the competence of auditors will improve audit quality at BPKP Representatives of Papua Province.

This finding shows that the higher the competence of an auditor, the higher the quality of the resulting audit. It is in line with the opinion of Christiawan (2002), which states that the higher the competence of auditors, the better the quality of the audit results. Another opinion is also by Efendy, (2010) which states that in government auditing, auditors are required to have and improve their abilities or expertise not only in audit methods and techniques but all matters relating to governance such as organizations, functions, programs and government activities.

Competence absolutely must be possessed by professional jobs such as; doctors, health workers, accountants, teachers and lecturers. Especially for an auditor, in completing an audit job, the auditor is required to have the expertise, which consists of elements of experience and knowledge.

Auditors must also have both general and specific knowledge, which includes knowledge of the area of auditing, 
accounting, and the characteristics of their clients, as stated by Suraida, (2005) that the inherent competence of an auditor is related to the professional expertise possessed by auditors as a result of formal education, professional examinations and participation in training, seminars and symposia. The results of this study are in line with the results of empirical studies by Aini (2009), Arianingtyas (2014), In and Asyik (2019), and Setyani (2015) which states that auditor competence has a positive and significant effect on the resulting audit quality.

\section{The Effect of Auditor Independence on Audit Quality at BPKP Representatives of Papua Province}

Similar to the above test, the results of the regression analysis also prove that the independence of auditors at BPKP Representatives of Papua Province has a positive and significant effect on audit quality. This can be proven by the regression coefficient, which shows if the independence of auditors at the BPKP Representatives of Papua Province increases, then the increase will be followed by an increase in audit quality. Thus it can be said that increased auditor independence will improve audit quality at BPKP Representatives of Papua Province. The results of the analysis also show that the audit quality is proven to be influenced by the independence of the BPKP Representative of Papua Province auditors. These results also illustrate that the better the independence of the auditors, the better the quality level of the results of the audit.

Independence must exist and be attached to an audience (Pattiasina et al., 2019). Moreover, the existence of an organization. The independence of BPKP as the government's internal auditor is often questioned because of the political involvement in all lines of government in Indonesia (Wulandari and Tjahjono, 2011). Another factor is the fact that there is cooperation with the object of examination that is too long and repetitive, which can cause vulnerability to the auditor's independence. Not to mention that the various facilities provided by the object of examination during the assignment can affect the objectivity of the auditor, and the auditor can be dishonest in disclosing facts that show the low integrity of the auditor (Alim et al., 2007).

The explanation above shows that the independence of an auditor must be upheld because an independent auditor is an impartial auditor or cannot be presumed to be impartial so that it does not harm any party (Pusdiklatwas, 2009). Real independence, which includes the attitude of independence in planning the audit program, the performance of auditors in verifying their work, and preparing reports. The results of this study are in line with the results of empirical studies by Alim et al. (2007), Aini (2009), Arianingtyas (2014), In and Asyik (2019), Samsi et al. (2013), and Setyani (2015) which states that auditor independence has a positive and significant effect on audit quality.

The Effect of Auditor Competence on Audit Quality at BPKP Representatives of Papua Province in Moderation by Auditor Ethics

The test results concerning whether there is a moderating effect of auditor ethics on the effect of auditor competence on audit quality shows that in fact, auditor ethics does not moderate the effect of auditor competence on audit quality at BPKP Representatives of Papua Province. It can be interpreted that the effect or moderating effect of auditors' ethics is proven not to increase or strengthen the influence of the auditors' competence of BPKP Representatives of Papua Province on the quality of the audit results they produce.

The findings of this study are consistent with the results of Aprianti (2010) but contrary to the findings of the study presented by In and Asyik (2019), which states that the influence of auditor ethics moderates the effect of auditor competence on the quality of audit results. Auditor ethics that do not moderate the effect of auditor competence on audit quality at BPKP Representatives of Papua Province is 
relatively due to various factors, including: (a) basically, the auditors of the BPKP Representatives of Papua Province have good ethical values or principles, namely; integrity, objectivity and they uphold the confidentiality of the resulting audit information. This is evidenced by the respondent's answer to the item X3.4 with the most massive mean or average value of 4.31, which states that "the auditor's code of ethics is in line with the noble values of auditors that I already have". It means that auditors at BPKP Representatives of Papua Province indirectly acknowledge that the noble values of an auditor's code of ethics such as; they already have integrity, objectivity, confidentiality and competence or it can be said that it is not because of a code of ethics that forces auditors to have integrity, objectivity, confidentiality and competence; (b) it can further be explained that the ethical values referred to above are in the form of behaviour; honest, courageous, wise and responsible (integrity), uphold impartiality (the element of objectivity), respect the value of confidentiality and ownership of information (confidentiality) already exists and is owned by the BPKP Auditor Representative of Papua Province. This means that these values are in them not because of professional demands that force or require them to have high values according to the Regulation of the Minister of Management and Bureaccration Reforms (or Permenpan) number PER/04/M.PAN/03/2008 mentioned above; and (c) the competence needed to support the quality of good audit results is relatively owned by the BPKP auditors for the Papua Province Representative Office. The better competence such as having knowledge, skills, experience, having technical competences in auditing, accounting, government administration and communication, having a Functional Auditor Position (JFA) certification and participating in continuing professional education and training will have the potential to produce good quality audits.
Effect of Auditor Independence on Audit Quality at BPKP Representatives of Papua Province in Moderation by Professional Commitment

In line with the above findings, the test results regarding the effect or moderating effect of professional commitment on the effect of auditor independence on audit quality prove that in fact, professional commitment does not moderate the effect of auditor independence on audit quality at BPKP Representatives of Papua Province. It can be interpreted that the effect or effect of moderating professional commitment is proven not to increase the magnitude of the influence of the independence of the BPKP Representatives of Papua Province auditors on audit quality.

It is in line with the effect of auditor ethics which does not moderate the effect of auditor competence on audit quality at BPKP Representatives of Papua Province. It is said to be in line because the BPKP auditors for the Representatives of Papua Province will have an adequate level of involvement with their profession. This involvement means that they will earnestly or work wholeheartedly in carrying out their duties and responsibilities as auditors. These findings are not in line with Jeffrey et al. (1996) who examined the relationship between independence and professional commitment, ethical understanding and obedience to rules, showing that accountants who have strong professional commitment and independence have more behavior towards compliance with rules.

\section{Conclusion}

Based on results then this study concludes that: (1) auditor competence is proven to have a positive and significant effect on audit quality. This can be proven by the regression coefficient, which shows that if the competence of auditors increases, the increase will be followed by an increase in audit quality. Thus it can be said that increasing the competence of auditors will improve audit quality at BPKP Representatives of Papua Province; (2) auditor independence has a positive and 
significant effect on audit quality. This can be proven by the regression coefficient, which shows that if auditor independence increases, the increase will be followed by an increase in audit quality. Thus it can be said that increased auditor independence will improve audit quality at BPKP Representatives of Papua Province; (3) the interaction or influence of auditor ethics does not moderate the effect of auditor competence on audit quality. It can be interpreted that the effect or moderating effect of auditor ethics is proven not to increase the magnitude of the influence of the auditor competence of BPKP Representatives of Papua Province on the resulting audit quality; (4) the interaction or influence of professional commitment does not moderate the effect of auditor independence on audit quality. It can be interpreted that the effect or moderating effect of professional commitment is proven not to increase the magnitude of the influence of the independence of the BPKP Representative of Papua Province auditors on the quality of the resulting audit; and (5) theoretically, the impact of auditors' competence and independence on audit quality, especially at BPKP representatives of Papua Province, mediated by ethics and professional commitment of auditors, proves that the good quality of audits at BPKP representatives of Papua Province is not only determined by the competence and independence of auditors but through mediated interactions by ethics and commitment professional auditors will then produce better audit quality so that these findings support the TPB theory.

This study suggests that: (1) increasing the competence of auditors is necessary to continue through education and training. Besides, it is also necessary to support periodic outreach to improve the auditor's understanding of the organizational structure, functions, programs and activities of the government when carrying out the audit function in government institutions. The activities referred to above will, of course, support the formation of useful competence for auditors; (2) the existing independence should be maintained or if it can be further improved. Increasing the relative independence of auditors can potentially be achieved through the participation of BPKP leaders. This means that if the leadership is able always to provide direction, motivation or experiences related to the independence that must be attached to the auditor, the opportunity to increase the independence of the BPKP Representative of Papua Province auditors will potentially be even better; and (3) this study only uses a questionnaire to determine the level of competence and independence of the BPKP Representative of Papua Province auditors so that the possibility of knowing weaknesses such as wrong answer choices, dishonesty and lack of seriousness in answering questions may occur. To reduce this weakness, it is suggested that after the results of the questionnaire are obtained, it should be followed by an interview to prove the honesty level of filling out the questionnaire.

The limitations encountered during this study include: (1) the sample under study is limited to the auditors only. It will be more interesting if the perceptions of the supervisor and auditee are also examined; and (2) there are still many variables measuring audit quality that are not analyzed in the model of this study. The implications of future studies that can be recommended through this study are: (1) this study in measuring the quality of audit results is limited to a few variables while the other variables that are not included are relatively numerous, so that further studies may use other variables such as monetary rewards, locus of control or audit experience. Future studies should not only use perceptions from auditors but can also use perceptions from supervisors or auditors as recommended by Kalbers and Fogarty (1995) in Larasati and Laksito (2013); (2) it is recommended that further studies needs to add samples that can be obtained from $B P K P$ of other provinces with the sampling method using area methods such as covering Maluku, North Maluku and West Papua Provinces (eastern Indonesia) so that 
the justification of this study can be relatively better; and (3) future studies should also consider using agency theory to describe whether there is a relationship of interest between the auditor and the auditee (in this case the government). The implication can be in the form of a work contract that regulates the proportion of rights and obligations of each party by maximizing utility so that the agent is expected to act in ways that are in accordance with the interests of the principal. On the other hand, the principal has the potential to provide appropriate incentives to agent so that an optimal work contract is achieved. The essence of agency theory is the design of appropriate contracts to align the interests of the principal and agent in the event of a conflict of interest. In this study, the government acts as the principal while the auditor as the agent.

\section{Data availability}

The research data can be accessed openly in the supporting document of the article (supplementary file).

\section{References}

Aini, K. (2009). Analisis faktor-faktor yang mempengaruhi kualitas audit: Studi empiris pada Kantor Akuntan Publik yang terdapat di Jakarta. Skripsi. Universitas Islam Negeri Syarif Hidayatullah Jakarta. http://repository.uinjkt.ac.id/dspace/handle/12 $\underline{3456789 / 17286}$

Ajzen, I. (2005). Attitudes, personality, and behavior, (Second Edition). England: McGraw-Hill Education.

https://psicoexperimental.files.wordpress.com/ 2011/03/ajzeni-2005-attitudes-personality-andbehaviour-2nd-ed-open-university-press.pdf

Alim, M. N., Hapsari, T., \& Purwanti, L. (2007). Pengaruh kompetensi dan independensi auditor terhadap kualitas audit dengan etika auditor sebagai variabel moderasi. https://smartaccounting. files.wordpress.com/20 11/03/auep08.pdf

Aprianti, D. (2010). Pengaruh kompetensi, independensi, dan keahlian profesional terhadap kualitas audit dengan etika auditor sebagai variabel moderasi: Studi kasus pada Kantor Akuntan Publik di Wilayah Jakarta Selatan. Skripsi. Universitas Islam Negeri Syarif Hidayatullah. http://repository.uinjkt.ac.id/dspace/handle/12 3456789/3225

Arianingtyas, D. (2014). Pengaruh kompetensi, independensi dan akuntabilitas terhadap kualitas audit dengan etika auditor sebagai variabel moderasi. Skripsi. Universitas Katolik Soegijapranata.

http://repository.unika.ac.id/id/eprint/908

Christiawan, Y. J. (2002). Kompetensi dan independensi akuntan publik: Refleksi hasil penelitian empiris. Jurnal Akuntansi dan Keuangan, 4(2), 79-91. http://jurnalakuntansi.petra.ac.id/index.php/ak u/article/view/15692

Efendy, M. T. (2010). Pengaruh kompetensi, independensi, dan motivasi terhadap kualitas audit aparat inspektorat dalam pengawasan keuangan daerah (Studi empiris pada Pemerintah Kota Gorontalo). Tesis. Universitas Diponegoro Semarang.

http://eprints.undip.ac.id/24634/1/Muh. Taufi q Efendy.pdf

Gasperz, J. (2014). Pengaruh tekanan anggaran waktu sebagai variabel moderasi terhadap hubungan antara faktor individu dan kualitas audit. Jurnal Dinamika Akuntansi Keuangan dan Perbankan, 3(1), 33-45.

https://www.unisbank.ac.id/ojs/index.php/fe9/ article/view $/ 2876$

Ghozali, I. (2005). Model persamaan struktural dengan Program AMOS versi 5.0. Semarang: Badan Penerbit UNDIP.

Hapsari, N. N. (2011). Pengaruh pengalaman auditor dan orientasi etika terhadap keputusan etis auditor negara dengan komitmen profesional sebagai variabel intervening. EL MUHASABA: Jurnal Akuntansi, 2(2). 1-19. https://doi.org/10.18860/em.v2i2.2369

Holt, A., \& Eccles, T. (2003). Accounting practice in the post-Enron era: The implications for financial statements in the property industry. Briefings in Real Estate Finance, 2(4), 326-340. https://doi.org/10.1002/bref.80

Indriyanto, A. R., \& Nasikin. (2014). Analisa faktor-faktor yang mempengaruhi kualitas audit yang dilakukan oleh Badan Pemeriksa Keuangan Republik Indonesia (Studi kasus pada BPK RI Perwakilan Provinsi Kepulauan Bangka Belitung). Jurnal Ilmiah Mahasiswa FEB, 3(1), 115.

https://jimfeb.ub.ac.id/index.php/jimfeb/article $\angle$ view/1455

Jeffrey, C., Weatherholt, N., \& Lo, S. (1996). Ethical development, professional commitment and rule observance attitudes: A study of auditors in Taiwan. The International Journal of Accounting, 31(3), 365-379. https://doi.org/10.1016/S00207063(96)90025-4

In, A. W. K., \& Asyik, N. F. (2019). Pengaruh kompetensi dan independensi terhadap kualitas audit dengan etika auditor sebagai variabel pemoderasi. Jurnal Imu dan Riset Akuntansi (JIRA), 8(8), 1-15. http://jurnalmahasiswa.stiesia.ac.id/index.php/ji $\mathrm{ra} /$ article/view/2451

Francis, J. R. (2004). What do we know about audit quality? The British Accounting Review, 36(4), 345-368. https://doi.org/10.1016/j.bar.2004.09.003

Lastanti, H. S. (2005). Tinjauan terhadap kompetensi dan independensi akuntan publik: Refleksi atas skandal keuangan. Media Riset Akuntansi, Auditing \& Informasi, 5(1), 85-98. https://trijurnal.lemlit.trisakti.ac.id/mraai/article $\angle$ view/2791 
Ludigdo, U. (2005). Mengembangkan etika di Kantor Akuntan Publik: Sebuah perspektif untuk mendorong perwujudan good governance.". Konferensi Nasional Akuntansi. Jakarta. http://www.arikamayanti.lecture.ub.ac.id/files/2 014/05/Etika-di-KAP-Unti-Ludigdo.pdf

Larasati, H., \& Laksito, H. (2013). Analisis variabel anteseden perilaku auditor internal dan konsekuensinya terhadap kinerja (Studi pada di BUMN Kota Semarang). Diponegoro Journal of Accounting, $354-367$. https://ejournal3.undip.ac.id/index.php/accoun ting/article/view/5947

Mayangsari, S. (2003). Analisis pengaruh independensi, kualitas audit, serta mekanisme corporate governance terhadap integritas laporan keuangan. Simposium Nasional Akuntansi VI. https://www.scribd.com/doc/171350047/Anali sis-Pengaruh-Independensi-Kualitas-Audit-SertaMekanisme-Corporate-Governance-TerhadapIntegritas-Laporan-Keuangan

Mulyadi. (2008). Sistem Akuntansi. Jakarta: Salemba Empat.

Nahuway, V. F., \& Tamaela, E. Y. (2020). Model efektifitas dan efisiensi e-procurement serta dampaknya terhadap kepuasan pengguna di Provinsi Maluku. Jurnal Maneksi, 9(1), 275-282. https://ejournalpolnam.ac.id/index.php/JurnalManeksi/article/ view/327

Najib, A. D. R. (2013). Pengaruh keahlian, independensi, dan etika terhadap kualitas audit: Studi pada auditor pemerintah di BPKP Perwakilan Provinsi Sul-Sel. Skripsi. Universitas Hasanuddin. http://103.195.142.59/opac/detailopac?id $=8253$

Pattiasina, V. (2017). Analisis pengaruh kualitas auditor, ukuran perusahaan, jumlah komite audit, kompleksitas operasi perusahaan terhadap audit delay dan opini audit yang diinterveing oleh audit lag. Future: Jurnal Manajemen dan Akuntansi, 5(1), 85-98.

http://jurnal.uniyap.ac.id/jurnal/index.php/futu $\mathrm{re} /$ article/view/301

Pattiasina, V., Latuheru, A., \& Ariani, D. F. I. (2019). Auditor skepticism: Papuan case. International Journal of Business, Economics \& Management, 2(1), 1-10. https://doi.org/10.31295/ijbem.v2n1.46

Pusdiklatwas, BPKP. (2009). Auditing. 3 ed. Modul Diklat Pembentukan Auditor Ahli. https://www.academia.edu/7688724/Judul Mo dul Auditing Dikeluarkan oleh Pusat Pendidik an dan Pelatihan Pengawasan BPKP dalam $r$ angka Diklat Sertifikasi JFA Tingkat Pembent ukan Auditor Ahli

Samadara, P. D. (2020). Internal service quality and employee performance. The International Journal of Social Sciences World, 2(01), 109-115. https://www.growingscholar.org/journal/index. $\mathrm{php} /$ TIJOSSW/article/view/76

Samsi, N., Riduwan, A., \& Suryono, B. (2013). Pengaruh pengalaman kerja, independensi, dan kompetensi terhadap kualitas audit: Etika auditor sebagai variabel pemoderasi. Jurnal Ilmu dan Riset Akuntansi, $\quad 1(2), \quad$ 207-226. https://www.scribd.com/document/324173864 LPengaruh-Pengalaman-Kerja-IndependensiDan-Kompetensi-Terhadap-Kualitas-Audit

Setyani, R. (2015). Pengaruh kompetensi, independensi, etika, motivasi, dan time budget pressure auditor terhadap kualitas audit (Studi empiris pada auditor pemerintah di Inspektorat Kabupaten Boyolali). Skripsi. Universitas Muhammadiyah Surakarta. http://eprints.ums.ac.id/37567/

Seralurin, Y. C., Larasati, R., \& Pattiasina, V. (2020). Institutional ownership as moderation of Execution Price Relationship and Employee Stock Ownership Program (ESOP). The International Journal of Social Sciences World, 2(2), 8599.

https://www.growingscholar.org/journal/index. $\mathrm{php} / \mathrm{TIJOSSW} /$ article/view/ 65

Suraida, I. (2005). Pengaruh etika, kompetensi, pengalaman audit dan risiko audit terhadap skeptisisme profesional auditor dan ketepatan pemberian opini akuntan publik. Sosiobumaniora: Jurnal Ilmuilmu Sosial dan Humaniora, 7(3), 186-202. http://jurnal.unpad.ac.id/sosiohumaniora/articl e/view/5351

Tamaela, E. Y., Pattiasina, V., Dasinapa, M. B., Marani, Y., \& Duri, J. A. (2020). Regional financial monitoring models with community participation and public policy transparency as moderators. International Journal of Psychosocial Rebabilitation, 24(2), 4223-4232. https://doi.org/10.37200/IJPR/V24I2/PR2007 45

Tammubua, M. H., \& Pattiasina, V. (2019). Quality academic services antecedent towards the level of students satisfaction in distance learning program unit Universitas Terbuka Jayapura. The International Journal of Social Sciences World, 1(01), 21-35.

https://www.growingscholar.org/journal/index. $\mathrm{php} / \mathrm{TIJOSSW} /$ article/view/6

Tan, C., \& Swan, L. (2020). Fraud on the performance of deposit money banks in China. The International Journal of Social Sciences World, 2(01), 1-9. https://www.growingscholar.org/journal/index. $\mathrm{php} / \mathrm{TIJOSSW} /$ article/view/9

Tjun, L. T., Marpaung, E. I., \& Setiawan, S. (2012). Pengaruh kompetensi dan independensi auditor terhadap kualitas audit. Laporan Penelitian. Jurusan Akuntansi Fakultas Ekonomi Universitas Kristen Maranatha. http://repository.maranatha.edu/643/

Wulandari, E., \& Tjahjono, H. K. (2011). Pengaruh kompetensi, independensi dan komitmen organisasi terhadap kinerja auditor pada BPKP Perwakilan DIY. Jurnal Bisnis: Teori dan Implementasi, 2(1), 27-44. https://journal.umy.ac.id/index.php/bti/article/ view $/ 2425$ 